\title{
Antioxidant status in women with uterine leiomyoma: relation with sex hormones
}

\author{
SNEŽANA PEJIĆ, ANA TODOROVIĆ, VESNA STOJILJKOVIĆ, \\ LJUBICA GAVRILOVIĆ, NATAŠA POPOVIĆ and SNEŽANA B. PAJOVIĆ
}

\author{
Laboratory of Molecular Biology and Endocrinology, "Vinča" Institute of Nuclear Sciences, \\ P.O. Box 522, University of Belgrade, 11001, Belgrade, Serbia
}

Manuscript received on October 18, 2013; accepted for publication on January 19, 2015

\begin{abstract}
Uterine leiomyomas are benign soft-tissues tumors that arise from uterine smooth muscle tissue. Etiopathogenesis of leiomyomas is not well understood. We aimed to examine whether antioxidant enzyme activities and lipid hydroperoxides level in patients with leiomyoma are influenced by changes in sex hormones and gonadotropins (estradiol (E2), progesterone, $\mathrm{FSH}$, and $\mathrm{LH}$ ) during menstrual cycle and in postmenopause. The material consisted of blood and uterine tissue specimens. Hormone concentrations were determined and assays for superoxide dismutase, catalase, glutathione peroxidase and glutathione reductase activities and lipid hydroperoxides concentration were performed. In blood of examined women, a significant difference in catalase, glutathione peroxidase and glutathione reductase activity was recorded among the phases. There was also a positive correlation between the estradiol/progesterone concentration and the catalase activity. Progesterone negatively correlated with lipid hydroperoxides level. In myoma tissue, we recorded a phase-related difference in lipid hydroperoxides level and activities of superoxide dismutase, glutathione peroxidase activities, and glutathione reductase. Negative correlation was observed between FSH and glutathione peroxidase. The results suggest that antioxidant status in patients with uterine leiomyoma is influenced by the changes in sex hormones during the menstrual cycle and in postmenopause, indicating a role of the observed relationship in the leiomyoma etiology.
\end{abstract}

Key words: antioxidant enzymes, lipid hydroperoxides, sex steroids, leiomyoma.

\section{INTRODUCTION}

Uterine leiomyomas are benign soft-tissues tumors that arise from uterine smooth muscle tissue (myometrium) and they are also called myomas or uterine fibroids. As non-cancerous growth arising from myometrium, leiomyomas are unrelated to the common forms of uterine cancer and uterine cervical cancer which typically

Correspondence to: Snežana Pejić

E-mail: snezana@vinca.rs arise from the endometrium (the uterine lining) or cervical epithelium, respectively. Currently, the pathogenesis and etiology of leiomyomas are not well understood but several risk factors have been identified. These include early menarche ( $<10$ years of age), nulliparity, age, hypertension, obesity, multiple uterine infections, tamoxifen use and ethnicity (Flake et al. 2003). Many studies are in agreement that African-American women present 2-3 times greater leiomyoma incidence 
than Caucasian, Asian or Hispanic women, as well as significantly higher serum levels of estrone (E1), estradiol (E2) and free E2 (Blake 2007). Some associations have been suggested with elevated levels of fibrotic growth factors and vascular abnormalities (Weintraub and Yemin 2011). Protective factors have also been identified, including smoking, multiparity, menopause, progestin-only injectable contraceptives, and oral contraceptive pills (Houston et al. 2001, Wallach and Vlahos 2004).

The growth of uterine leiomyomas is considered to be influenced by estrogen (E2), growth hormone, and progesterone. Such dependence is indicated by the fact that most of these tumors are diagnosed during the reproductive years when they exhibit maximum growth, and regress after menopause (Evans and Brunsell 2007). Many investigations also indicated differences between non-transformed and leiomyoma tissue concentrations of estrogens and progesterone and their respective receptors (ER- $\alpha$, ER- $\beta$ and PR-A, PR-B) (Ciavattini et al. 2013). Leiomyomas may occasionally increase in size during pregnancy, which can be caused by hormones, but also by increased blood flow and edema (Wallach and Vlahos 2004).

Reactive oxygen species (ROS) have many physiological regulatory functions and are also implicated in the development of a wide spectrum of diseases (Alfadda and Sallam 2012). The mammalian cell has an adequate antioxidant system to cope with excessive ROS production under normal physiological conditions. This system consists of antioxidant (AO) vitamins, thiolcontaining compounds such as reduced glutathione (GSH), and antioxidant enzymes, including superoxide dismutase (SOD), catalase (CAT), glutathione peroxidase (GPx) and glutathione reductase (GR). Variations in antioxidant capacity may influence individual susceptibility to some diseases associated with the deleterious effects of oxidative reactions (Shinde et al. 2012).
The relationship between sex hormones and antioxidant system was investigated during regular cyclic changes of endometrium, and in the reproductive system disorders. SOD plays an important role in maintaining luteal cell integrity and steroidogenic capacity (Sugino and Kato 1994) and its expression in endometrial stromal cells is associated with decidualization (Sugino et al. 2000). In amenorrheic women, estradiol but not progestagen replacement therapy stimulated erythrocyte GPx activity (Massafra et al. 2000). It is believed that estrogen decreases free radical production, and depressed estrogen synthesis in postmenopausal women is responsible for enhanced oxidative stress (Agarwal et al. 2005). In endometrial cells of women with endometriosis, Andrade et al. (2013) reported elevated levels of $\mathrm{H}_{2} \mathrm{O}_{2}$ and lower CAT activity, along with antiapoptotic effect of estradiol (E2), increased cell proliferation and increased mitogen-activated protein kinase (ERK) phosphorylation. These results support the findings of high endogenous oxidative stress in endometriotic cells due to alterations of ROS detoxification pathways and activation of ERK1/2, similar to tumor cells (Ngô et al. 2009).

We have previously shown that antioxidant status is altered in patients with endometrial hyperplasia or adenocarcinoma in comparison to women diagnosed with polyp or leiomyoma (Pejić et al. 2008, 2009). The aim of this study was to examine whether AO enzyme activities and lipid hydroperoxides $(\mathrm{LOOH})$ level in patients with uterine leiomyoma are influenced by changes in sex hormones during the menstrual cycle and in postmenopause.

\section{MATERIALS AND METHODS}

SUBJECTS

The material used in this study consisted of 30 blood and tissue specimens of women admitted to the Department of Gynecology and Obstetrics for gynecological evaluation within routine checkups or for abnormal uterine bleeding (Metrorrhagia prolongata, Metrorrhagia recidivans, Metrorrhagia 
postmenopausi). They were diagnosed with uterine leiomyoma, confirmed by histopathological findings. Study was conducted prospectively and it was approved by the Human Studies Ethics Committee of the Clinical Center. The protocol was consistent with the World Medical Association Declaration of Helsinki (Ethical Principles for Medical Research Involving Human Subjects). All specimens were taken after obtaining the informed consent and none of the subjects had undergone hormone therapy or any other medical treatment in the last 6 months. Patients were divided as follows: 11 in the follicular phase (F) (age, 39-49 yr; median $45 \mathrm{yr}$ ), 10 in the luteal phase (L) (age, 37-50 yr; median $44 \mathrm{yr}$ ), 9 in the postmenopause (PM) (age, 51-70 yr, median $56 \mathrm{yr}$ ).

\section{SAMPLES}

Venous blood samples were collected into heparinized tubes on the same day of uterine biopsy and aliquoted immediately. For SOD assay (OxisResearch ${ }^{\mathrm{TM}}$ ), blood was centrifuged at $2500 \mathrm{~g}$ for $5 \mathrm{~min}$. Plasma was discarded and pellet was resuspended in 4 packed-cell volume of ice-cold demineralized ultrapure water (MilliQ reagent grade water system, Millipore Corp., Bedford, MA, USA). After addition of ethanol/ chloroform extraction reagent $(62.5 / 37.5 \mathrm{vol} /$ vol) to remove hemoglobin interference, samples were centrifuged at $3000 \mathrm{~g}$ for $10 \mathrm{~min}$ (Eppendorf centrifuge 5417, Eppendorf AG, Hamburg, Germany). Upper aqueous layer was collected and kept at $-70{ }^{\circ} \mathrm{C}$ until assay.

Myoma samples were washed in saline solution and homogenized in phosphate buffer containing $0.05 \mathrm{MKH}_{2} \mathrm{PO}_{4}$ and 1 mMEDTA, pH 7.8 (1 g tissue per $2 \mathrm{ml}$ buffer) in a Teflon/glass homogenizer (Spindler and Hoyer, Göttingen, Germany) and frozen at $-70{ }^{\circ} \mathrm{C}$ for $20 \mathrm{~h}$ in order to disrupt cell membranes. For SOD assay $\left(\right.$ OxisResearch ${ }^{\mathrm{TM}}$ ), thawed homogenates were vortexed $1 \mathrm{~min}$ and centrifuged at $8600 \mathrm{~g}$, for $20 \mathrm{~min}$ at $4{ }^{\circ} \mathrm{C}$ (Eppendorf centrifuge 5417, Eppendorf AG, Hamburg, Germany). According to manufacturer's recommendation, after addition of ethanol/chloroform extraction reagent $(62.5 / 37.5 \mathrm{vol} / \mathrm{vol})$ to completely remove hemoglobin interference, samples were centrifuged at $6000 \mathrm{~g}$ for $20 \mathrm{~min}$, at $4{ }^{\circ} \mathrm{C}$ (Beckman centrifuge J2-21, Beckman Instruments Inc., Palo Alto, CA, USA). Upper aqueous layer was collected and kept at $-70{ }^{\circ} \mathrm{C}$ until assay. The enzyme activities and lipid hydroperoxide (LOOH) concentration were monitored spectrophotometrically (Perkin Elmer Spectrophotometer, Lambda 25, Perkin Elmer Instruments, Norwalk, CT, USA).

The specific enzyme activities were expressed as Units (U) or mU per milligram of total cell protein (U or $\mathrm{mU} / \mathrm{mg}$ protein). $\mathrm{LOOH}$ concentration was expressed as nmol/mg protein. Determination of protein concentration was performed in tissues homogenates by the method of Lowry et al. (1951) and expressed as $\mathrm{mg} / \mathrm{ml}$. Plasma folliclestimulating hormone (FSH), luteinizing hormone (LH), estradiol (E2) and progesterone (P) levels were analyzed using standard radioimmunoassay (RIA) methods by the hormone analysis laboratory.

\section{ASSAYS}

ASSAY OF SOD ACTIVITY

Determination of total SOD activity was performed using Oxis Bioxytech ${ }^{\circledR}$ SOD-525 ${ }^{\text {TM }}$ Assay (Oxis International, Inc., Portland, OR, USA). The method is based on SOD-mediated increase of autoxidation of 5,6,6a11b-tetrahydro-3,9,10-tryhydroxybenzo[c] fluorene in aqueous alkaline solution to yield a chromophore with maximum absorbance at $525 \mathrm{~nm}$. The SOD activity is determined from the ratio of the autoxidation rates in the presence (Vs) and in the absence (Vc) of SOD. One SOD-525 activity unit is defined as the activity that doubles the autoxidation rate of the control blank.

\section{ASSAY OF CAT ACTIVITY}

CAT activity was determined by the method of Beutler (1982). The reaction is based on the 
rate of $\mathrm{H}_{2} \mathrm{O}_{2}$ degradation by catalase, contained in the examined samples. The reaction was performed in an incubation mixture containing $1 \mathrm{M}$ Tris-HCl, 5mM EDTA, $\mathrm{pH}$ 8.0, and monitored spectrophotometrically at $230 \mathrm{~nm}$. One unit of CAT activity is defined as $1 \mu \mathrm{mol}$ of $\mathrm{H}_{2} \mathrm{O}_{2}$ decomposed per minute under the assay conditions.

ASSAY OF GPX ACTIVITY

GPx activity was assessed using the Oxis Bioxytech ${ }^{\circledR}$ GPx-340 ${ }^{\mathrm{TM}}$ Assay (Oxis International, Inc., Portland, OR, USA), based on the principle that oxidized glutathione (GSSG) produced upon reduction of an organic peroxide by GPx, is immediately recycled to its reduced form (GSH) with concomitant oxidation of NADPH to NADP+. The oxidation of NADPH was monitored spectrophotometrically as a decrease in absorbance at $340 \mathrm{~nm}$. One GPx-340 unit is defined as $1 \mu \mathrm{mol}$ of NADH oxidized per minute under the assay conditions.

\section{ASSAY OF GR ACTIVITY}

Activity of GR was measured using the Oxis Bioxytech ${ }^{\circledR}$ GR $-340^{\mathrm{TM}}$ Assay (Oxis International, Inc., Portland, OR, USA). Assay is based on the oxidation of NADPH to NADP+ during the reduction of oxidized glutathione (GSSG), catalyzed by a limiting concentration of glutathione reductase. The oxidation of NADPH was monitored spectrophotometrically as a decrease in absorbance at $340 \mathrm{~nm}$. One GR-340 unit is defined as $1 \mu \mathrm{mol}$ of NADH oxidized per minute under the assay conditions.

\section{LIPID HYDROPEROXIDES}

Concentration of $\mathrm{LOOH}$ was measured by Oxis Bioxytech ${ }^{\circledR}$ LPO-560 ${ }^{\mathrm{TM}}$ Assay (Oxis International, Inc., Portland, OR, USA), which is based on the ability of hydroperoxides to react with an excess of $\mathrm{Fe}^{2+}$ at a low $\mathrm{pH}$ when the xylenol orange $(\mathrm{XO})$ dye is present. The amount of $\mathrm{Fe}^{3+}$ generated by this reaction is measured as the Fe-XO complex at $560 \mathrm{~nm}$, as demonstrated by the following equations:

$$
\begin{gathered}
\mathrm{Fe}^{2+}+\mathrm{ROOH} \rightarrow \mathrm{Fe}^{3+}+\mathrm{OH}^{-}+\mathrm{RO}^{\bullet} \\
\mathrm{Fe}^{3+}+\mathrm{XO} \rightarrow \mathrm{Fe}^{-} \mathrm{XO}^{\bullet}(\text { dye })
\end{gathered}
$$

Since hydrogen peroxide content in many biological samples is much higher than that of other hydroperoxides, samples were pretreated with catalase to decompose the existing $\mathrm{H}_{2} \mathrm{O}_{2}$ and eliminate the interference.

STATISTICS

Statistical analysis was carried out with the use of the Kruskal-Wallis test and the Dunn's post hoc test, which considered the unequal and small sample sizes we used in this study. A linear regression model was used to evaluate associations between hormonal and antioxidant variables. Before plotting the data in the regression study, the normality test on the variables was performed and the values of estradiol and progesterone were log-transformed. The 95\% confidence intervals (CIs) for the regression lines were calculated. Two-tailed $p$ values are given throughout. All data were analyzed using GraphPad Prism software.

\section{RESULTS}

The phase related concentrations of gonadotropins and sex hormones are reported in Table I. Significant changes were observed in FSH $(\mathrm{H}=8.63, \mathrm{p}<0.05$, Kruskal-Wallis) and in estradiol concentrations $(\mathrm{H}=6.74, \mathrm{p}<0.05$, Kruskal-Wallis $)$.

ANTIOXIDANT PARAMETERS AND CORRELATION STUDY WITH SEX HORMONES IN BLOOD

The phase related changes of $\mathrm{LOOH}$ concentrations and AO enzyme activities in the blood of examined patients are shown in the Figure 1. The LOOH concentration and SOD activity were not significantly different with respect to the phase. The activity of CAT varied significantly $(\mathrm{H}=6.17$, 
$\mathrm{p}<0.05$, Kruskal-Wallis) and it was lower in postmenopause ( $\mathrm{H}=6.36, \mathrm{H}=6.83$, respectively postmenopause than in luteal phase $(\mathrm{p}<0.05, \quad \mathrm{p}<0.05$, Kruskal-Wallis). The activities of both Dunn test). GPx and GR showed significant enzymes were higher in postmenopause than in changes of enzyme activities from $F$ phase toward $F$ phase $(p<0.05$, Dunn test).

\section{$\mathrm{LOOH}$}
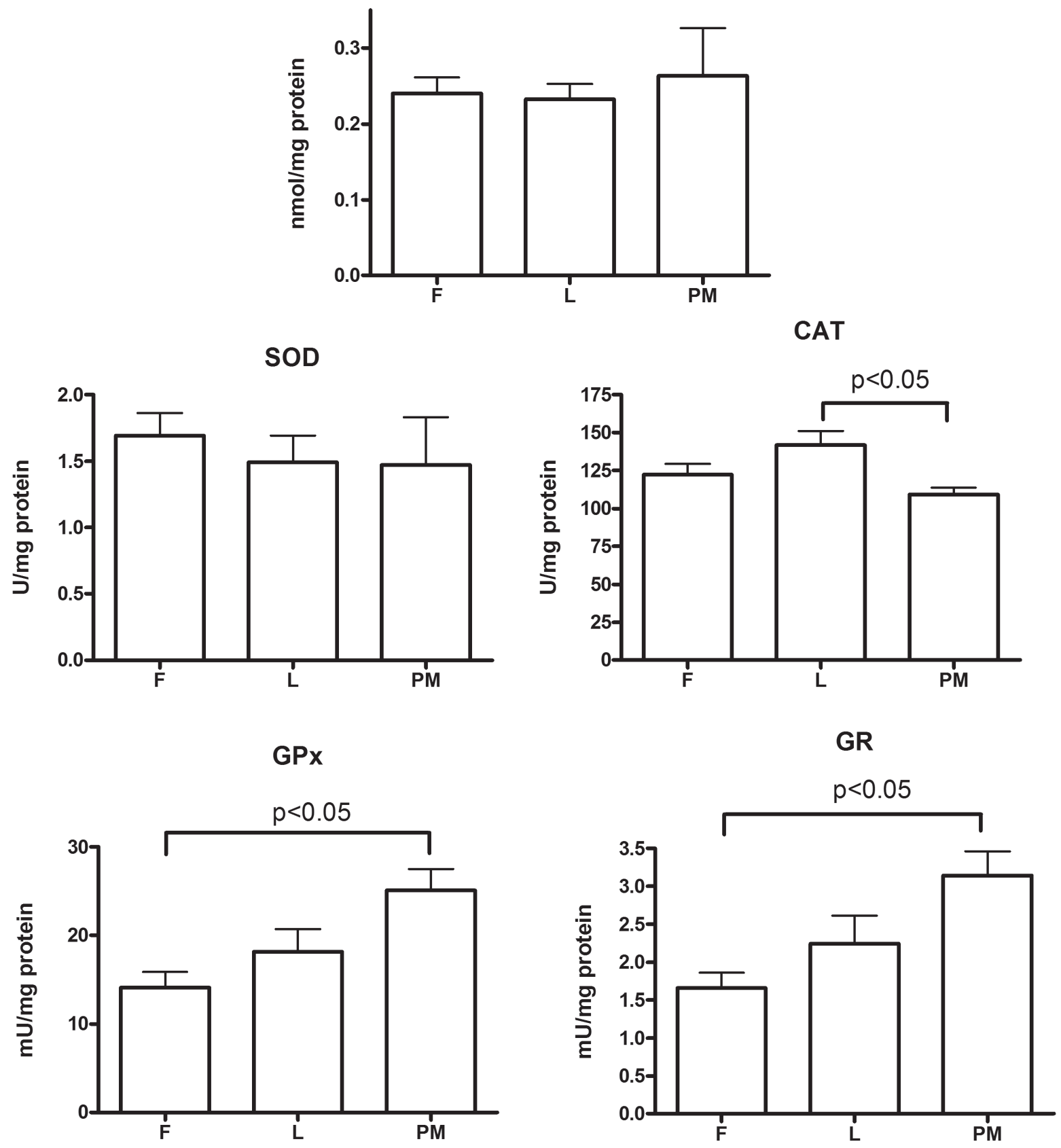

Figure 1 - Changes in LOOH concentrations and AO enzyme activities in follicular phase (F), luteal phase (L) and postmenopause $(\mathrm{PM})$ in blood of patients with uterine leiomyoma. Data are shown as mean \pm SEM. $P$ values refer to the results of the Dunn test. 
TABLE I

Changes in hormone levels during follicular phase, luteal phase and in postmenopause (Data are expressed as mean $\pm \mathrm{SEM} ;{ }^{*} \mathbf{p}<0.05$ ).

\begin{tabular}{c|c|c|c}
\hline & Follicular phase & Luteal phase & Postmenopause \\
\hline FSH $(\mathrm{U} / \mathrm{L})^{*}$ & $12.94 \pm 2.20$ & $4.23 \pm 1.35$ & $29.95 \pm 0.95$ \\
Median & 10.80 & 4.10 & 29.95 \\
(Min/Max) & $(7.80-20.10)$ & $(1.90-6.80)$ & $(29.00-30.90)$ \\
\hline LH (U/L) & $4.62 \pm 1.57$ & $2.00 \pm 1.24$ & $5.75 \pm 2.25$ \\
Median & 3.10 & 0.95 & 5.75 \\
(Min/Max) & $(2.20-10.70)$ & $(0.40-5.70)$ & $(3.50-8.00)$ \\
\hline Estradiol (pg/ml) & $50.05 \pm 10.65$ & $245.70 \pm 22.98$ & $25.43 \pm 10.70$ \\
Median & 58.55 & 234.00 & 20.30 \\
Min/Max) & $(18.50-64.60)$ & $13.63 \pm 8.85$ & $(10.00-46.00)$ \\
\hline Progesterone (nmol/L) & $6.58 \pm 2.26$ & 5.70 & $1.05 \pm 0.05$ \\
Median & 5.00 & $(3.00-40.10)$ & 1.05 \\
Min/Max) & $(1.60-14.70)$ & & $(1.00-1.10)$ \\
\hline
\end{tabular}

The linear regression analysis of individual hormonal variables against antioxidant parameters in blood (Fig. 2) showed significant positive correlation between the estradiol concentration and CAT activity $(\mathrm{r}=0.62, \mathrm{p}<0.05)$, progesterone concentration and CAT activity $(r=0.74, p<0.01)$, as well as a negative correlation between progesterone and $\mathrm{LOOH}$ concentrations $(\mathrm{r}=-0.65, \mathrm{p}<0.05)$. No significant correlations were found between other hormones and antioxidant variables.

\section{ANTIOXIDANT PARAMETERS AND CORRELATION STUDY WITH}

\section{SEX HoRmones IN TISSUE}

The phase related changes of $\mathrm{LOOH}$ concentrations and $\mathrm{AO}$ enzyme activities in uterine leiomyoma of examined patients are shown in Figure 3. Differently from the blood pattern, the $\mathrm{LOOH}$ concentration significantly differed with respect to the phase $(\mathrm{H}=6.68, \mathrm{p}<0.05$, Kruskal-Wallis $)$. In follicular phase, it was significantly lower than in postmenopause $(p<0.05$, Dunn test) but not in comparison to the $\mathrm{L}$ phase.

The activity of SOD was significantly different $(\mathrm{H}=7.48, \mathrm{p}<0.05$, Kruskal-Wallis), and it was higher in luteal phase in comparison to both, follicular phase and postmenopause $(p<0.05$, Dunn test). The activity of CAT was stable, while the activities of GPx and GR varied significantly
$(\mathrm{H}=6.78 ; \mathrm{H}=7.12, \mathrm{p}<0.05$, respectively, KruskalWallis). Furthermore, the activities of both GPx and GR were significantly higher in luteal phase than in postmenopause $(\mathrm{p}<0.05$, Dunn test).

The linear regression analysis of hormone levels and the examined AO parameters in uterine leiomyoma tissue (Fig. 4) showed negative correlation between FSH level and GPx activity $(\mathrm{r}=-0.64, \mathrm{p}<0.01)$. No significant correlations were found between other hormones and antioxidant variables.

\section{DISCUSSION}

This study shows the changes of AO enzymes activities and $\mathrm{LOOH}$ level in blood and uterine leiomyoma tissue of cycling women, and women in postmenopause. In the blood of these patients, we found no difference in $\mathrm{LOOH}$ concentration and SOD activity. The CAT activity was lower in the postmenopause than in the luteal phase and GPx and GR activities were higher in the postmenopause than in F phase. As in healthy women (Burger et al. 2007), patients with fibroids examined in this study, also had a decline of estradiol level in the postmenopause compared to women with regular cycle. At higher concentrations estradiol has some antioxidant properties while its decline in postmenopause is associated with pro-oxidant effects. These effects 

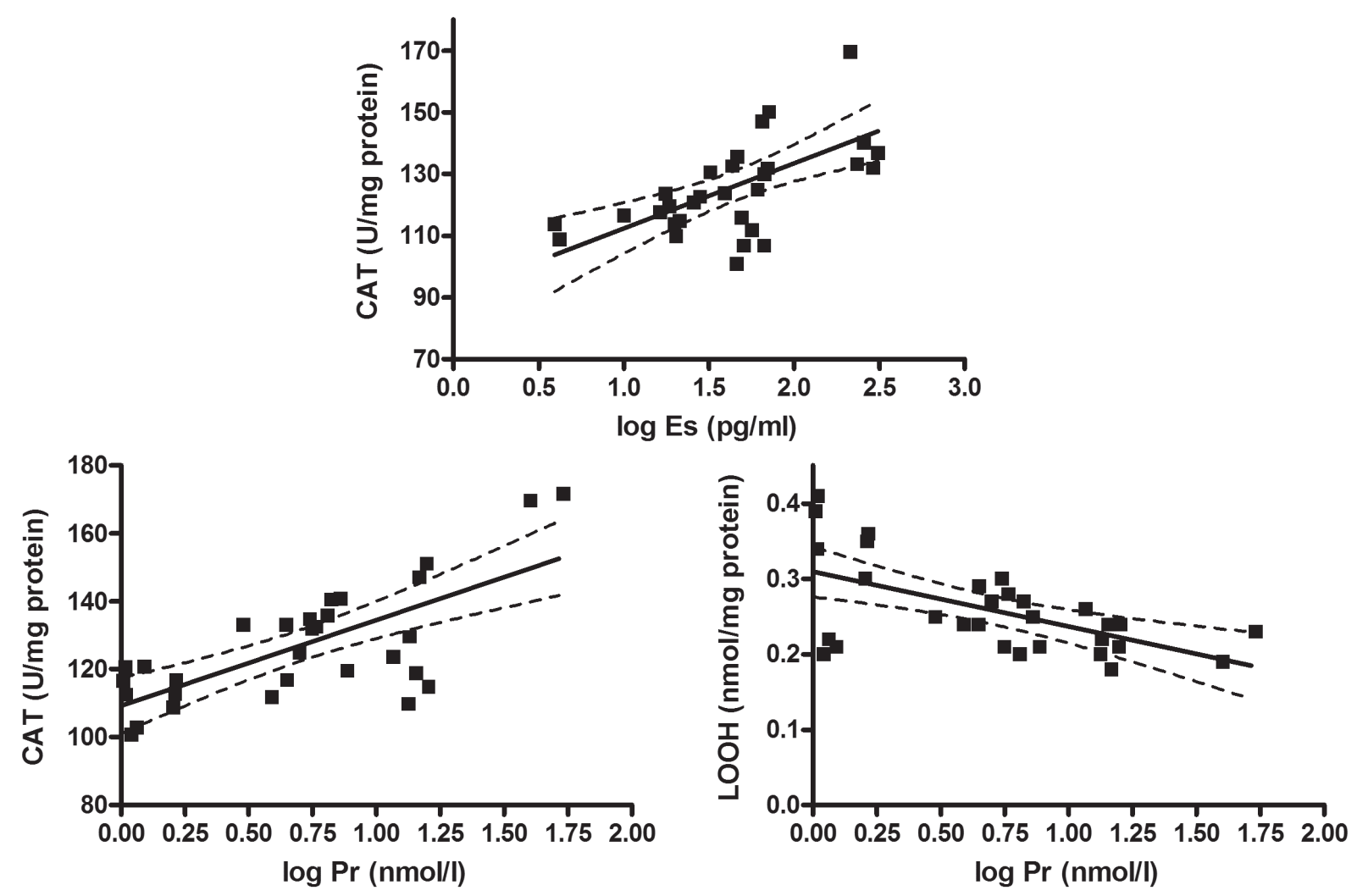

Figure 2 - Linear regression line and 95\% CI to study the relationship between $\log$ Es/Pr and CAT activity, log Pr and LOOH concentration in the blood of patients with uterine leiomyoma.

include oxidation of bases and formation of DNA adducts (Doshi and Agarwal 2013).

Studies of healthy women and those with hormonal and ovarian disorders provided different results about the influence of sex hormones on AO enzymes activity during menstrual cycle. BednarekTupikowska et al. (2001) found no significant differences of SOD activity in erythrocytes of healthy premenopausal and postmenopausal women. During the menstrual cycle, Massafra et al. (2000) observed no cycle-phase dependent changes in SOD and CAT activities as well as no correlation between activities of these enzymes and FSH, LH, estradiol or progesterone concentrations. Women with polycystic ovary syndrome were found to have higher SOD activity in blood than healthy women (Sabuncu et al. 2001). In women with ovulatory and anovulatory menstrual cycles it was observed that non-ovulating women had lower plasma 17-beta-estradiol concentrations than the ovulating ones, in both follicular and luteal phase, while the progesterone concentration was lower only in the luteal phase (Lutosłavska et al. 2003). They also found higher SOD activity in non-ovulating women and no difference in CAT, GPx and GR activities in both groups of women with respect to the phase of the menstrual cycle. In ovulating women, inverse correlation was demonstrated between circulating estradiol and SOD activity (Lutosłavska et al. 2003).

In leiomyoma tissue, we observed similar pattern of SOD, GPx and GR activities, which were lower in the $\mathrm{F}$ phase and in the postmenopause than in the L phase. Furthermore, the elevated level of LOOH was recorded in postmenopause. Decreased activity of antioxidant enzymes, along with changes 


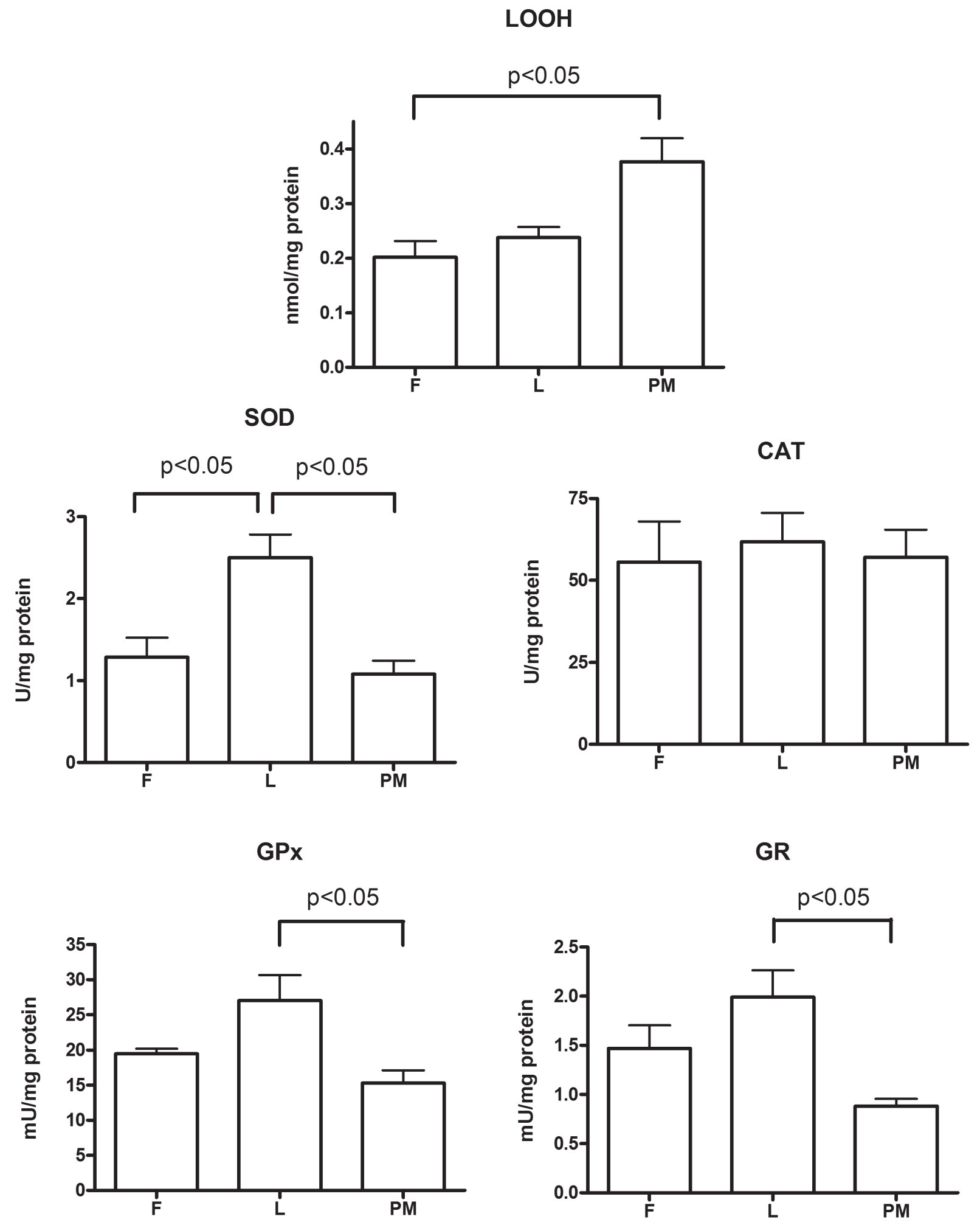

Figure 3 - Changes in LOOH concentrations and AO enzyme activities in follicular phase (F), luteal phase (L) and postmenopause (PM) in uterine leiomyoma tissue. Data are shown as mean \pm SEM. $P$ values refer to the results of the Dunn test. 


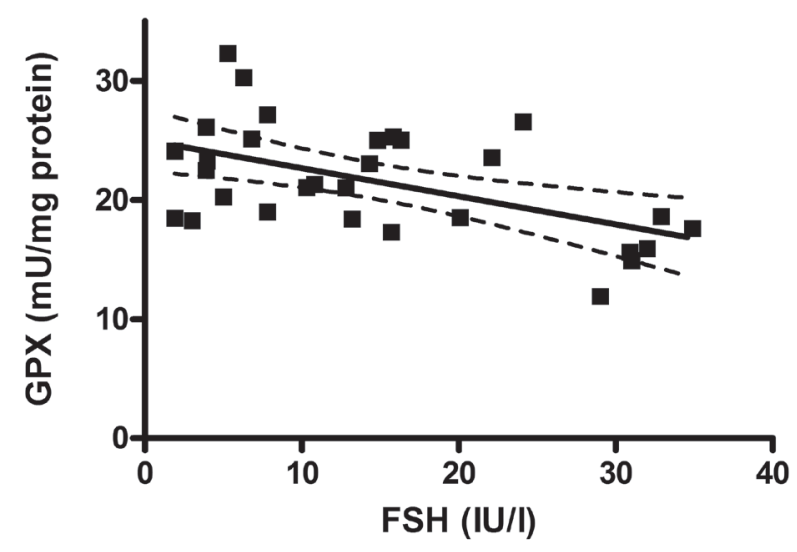

Figure 4 - Linear regression line and 95\% CI to study the relationship between $\log$ FSH and GPx activity in uterine leiomyoma tissue.

of hormones and lipid peroxides level, indicate that postmenopausal women are particularly sensitive to peroxidative stress. Based on current data, GPx was shown to be influenced by hormones. In women with amenorrhea, Massafra et al. (1996, 1997) found that estradiol treatment, but not progestogen, stimulates GPx activity in erythrocytes of these patients. In addition, the increased activities of GPx and CAT in erythrocytes were observed during extended use of oral contraceptives (Massafra et al. 1993, 1996). Healthy women with a normal ovulatory cycle manifested changes in the activity of GPx depending on the phase of the cycle, so the activity of this enzyme was higher in the late stage of the $\mathrm{F}$ phase in comparison to the earlier L phase (Massafra et al. 1998, 2000). There was a positive correlation between serum estradiol and changes in GPx activity relative to the phase of the menstrual cycle (Massafra et al. 2000, Bednarek-Tupikowska et al. 2001). Similar results regarding GPx activity in healthy women with regular cycles were obtained by Serviddio et al. (2002). The activity of this enzyme increased in the follicular phase and decreased in the luteal phase. These authors also showed a positive correlation between the activity of GPx and LH concentrations in healthy women.

In this study, we found inverse correlation between GPx and FSH level in leiomyoma tissue. In the blood of the examined women, CAT activity was positively correlated with estradiol and progesterone, while LOOH concentration was inversely correlated to progesterone. Reports suggested a connection between CAT activity and estrogen exposure. Castanho et al. (2012) reported antagonizing effect of hormone therapy on CAT activity in menopausal women, while results of Vaishali et al. (2005) indicated higher CAT activity and lower GPx activity in blood of premenopausal women, compared with those in postmenopause. The relation we observed might indicate that leiomyoma patients have certain specificity in which although CAT activity is lower, GPx activity is still elevated to cope with a free radical production in blood, even in postmenopause. In addition to estrogen levels, cellular redox state may also influence CAT activity. It was observed that long-term oxidative stress reduces stability and half-life of catalase by stimulating ubiquitination and proteosomal degradation of the enzyme (Cao et al. 2003). However, in maintenance of cellular $\mathrm{H}_{2} \mathrm{O}_{2}$ levels, the harmonized CAT and GPX activity is most important since $\mathrm{H}_{2} \mathrm{O}_{2}$ plays an important role in many physiological processes like cell cycle and proliferation ( $\mathrm{Li}$ et al. 2009), regulation of enzyme activity (Ferrer-Sueta et al. 2011), redox signalling (Sies 2014) and apoptosis (Andrade et al. 2013).

The role of progesterone in lipid peroxidation and AO body's defence is not clarified. Different results have been obtained, mainly as a consequence of progesterone preparations for hormone replacement therapy in postmenopausal women. Tranquilli et al. (1995) showed that treatment with medroxyprogesterone (MPA), whether used alone or in combination with estradiol, has antioxidant effects. On the other hand, Bednarek-Tupikowska et al. (2004) did not show the antioxidant effect of progesterone, because MPA in combination with estradiol, as part of hormone therapy, did not increase the observed antioxidant effect of estradiol. Negative correlation between the levels of progesterone and $\mathrm{LOOH}$ that we recorded 
in patients with fibroids could also indicate the antioxidant properties of progesterone.

Some data suggest a greater impact of progesterone on the growth of uterine leiomyoma (Rein 2000), compared to estrogen, although others emphasize the role of estradiol (Barbarisi et al. 2001, Kovács et al. 2001) or of both steroids (Neuwirth and Moritz 2008). It is still unclear how estradiol and progesterone affect the growth and development of fibroids since during pregnancy there is a decrease in the size of fibroids, when circulating levels of these hormones are high (Strobelt et al. 1994). Recent studies suggest that progesterone exerts a dualistic, stimulatory and inhibitory, effect on cell survival and growth of fibroids, depending on local growth factors surrounding these tissues (Maruo et al. 2004). It is also believed that sex steroids promote development of leiomyomas by stimulating inappropriate expression of growth factors. Estrogen and progesterone act as physiologic regulators of gene expression by activating nuclear receptors that are, themselves, transcription factors. In this way estrogen and progesterone play a key role in regulating genes that direct cell growth (Neuwirth and Moritz 2008). Studies already supported a role of these hormones in leiomyoma growth through a feedback mechanisms and activation of MAP-kinase pathways (Yu et al. 2010).

It was also observed that the agonistgonadotropin releasing hormone $(\mathrm{GnRH})$ inhibits steroidogenesis and induces pharmacological menopause. Through this mechanism, GnRH can reduce fibroid volume by $50 \%$ within 3-6 months (Wang et al. 2002, Maruo et al. 2004). Clinical evidence of sex steroids involvement in leiomyoma growth can be seen with the shrinkage of leiomyoma during menopause and after GnRH administration in hypoestrogenic and hypoprogesterone states (Neuwirth and Moritz 2008).

The pathogenesis of uterine leiomyoma is still not clarified. Although all women of reproductive age experience significant exposure to estrogen, it is unclear what renders some individuals susceptible to leiomyoma formation. Our study suggests that in blood and uterine leiomyoma tissue, some AO enzymes are regulated by sex hormones. Whether the relation between endometrial AO status and changes of sex hormones level plays a role in its etiology, remains to be evaluated.

\section{ACKNOWLEDGMENTS}

This work was financially supported by the Ministry of Education, Science and Technological Development, Republic of Serbia (Grants 41027, 41022).

\section{RESUMO}

Leiomiomas uterinos são tumores benignos dos tecidos moles que surgem da musculatura lisa uterina. A etiopatogênese dos leiomiomas não é bem compreendida. Nós objetivamos examinar se a atividade de enzimas antioxidantes e o nível de hidroperóxidos de lipídios em pacientes com leiomioma são influenciados por mudanças nos hormônios sexuais e nas gonadotropinas (estradiol (E2), progesterona, FSH e LH) durante o ciclo menstrual e na pós-menopausa. O material consistiu em sangue e espécimes de tecido uterino. As concentrações hormonais foram determinadas e foram realizados ensaios de atividade de superóxido dismutase, catalase, glutationa peroxidase e glutationa redutase e a concentração de hidroperóxidos de lipídios foi mensurada. No sangue das mulheres examinadas, foi verificada uma diferença significativa entre as fases nas atividades de catalase, glutationa peroxidase e glutationa redutase. Também houve uma correlação positiva entre a concentração de estradiol/progesterona e a atividade de catalase. A progesterona correlacionou negativamente com níveis de hidroperóxidos de lipídios. No tecido do mioma, foi verificada uma diferença relacionada à fase nos níveis de hidroperóxidos de lipídios e nas atividades de superóxido dismutase, glutationa peroxidase e glutationa redutase. Uma correlação negativa foi observada entre FSH e glutationa peroxidase. Os resultados sugerem que o estado antioxidante em pacientes com leiomioma uterino é influenciado por mudanças nos 
hormônios sexuais durante o ciclo menstrual e na pósmenopausa, indicando um papel da relação observada na etiologia do leiomioma.

Palavras chave: enzimas antioxidantes, hidroperóxidos de lipídios, esteroides sexuais, leiomioma.

\section{REFERENCES}

Agarwal A, GUPtA S AND SHARMA RK. 2005. Role of oxidative stress in female reproduction. Reprod Biol Endocrinol 14: 3-28.

AlfadDA AA AND SALLAM RM. Reactive oxygen species in health and disease. J Biomed Biotechnol 2012: 936486.

ANDRADE SS ET AL. 2013. 17- $\beta$-estradiol and steadystate concentrations of $\mathrm{H}_{2} \mathrm{O}_{2}$ : antiapoptotic effects in endometrial cells from patients with endometriosis. Free Radic Biol Med 60: 63-72.

Barbarisi A, Petillo O, Di lieto A, Melone maB, Margarucci S, CANNAS M AND Peluso G. 2001. 17-b estradiol elicits an autocrine leiomyoma cell proliferation: evidence for a stimulation of protein kinase-dependent pathway. J Cell Physiol 186: 414-424.

BedNAREK-TUPIKOWSKA G, BOHDANOWICZ-PAWLAK A, BIDZIŃSKA B, MiLEWICZ A, ANTONOWICZ-JUCHNIEWICZ J AND ANDRZEJAK R. 2001. Serum lipid peroxide levels and erythrocyte glutathione peroxidase and superoxide dismutase activity in premenopausal and postmenopausal women. Gynecol Endocrinol 15: 298-303.

BEDNAREK-TUPIKOWSKA G, BOHDANOWICZ-PAWLAK A, BIDZINSKA B, MiLEWICZ A, ANTONOWICZ-JUCHNIEWICZ J AND ANDRZEJAK R. 2004. Serum lipid peroxides and total antioxidant status in postmenopausal women on hormone replacement therapy. Gynecol Endocrinol 19: 57-63.

BeUtLER E. 1982. Catalase. In: BEUTLER E (Ed), Red Cell Metabolism, a manual of biohemical methods. New York: Grune and Stratton, USA, p. 105-106.

BLAKE RE. 2007. Leiomyomata uteri: Hormonal and molecular determinants of growth. J Natl Med Assoc 99: 1170-1184.

Burger HG, Hale GE, Robertson DM AND DENNERSTEIN L. 2007. A review of hormonal changes during the menopausal transition: focus on findings from the Melbourne women's midlife health project. Hum Reprod Update 13: 559-565.

CAO C, Leng Y, LiU X, Yi Y, Li P AND Kufe D. 2003. Catalase is regulated by ubiquitination and proteosomal degradation. Role of the c-Abl and Arg tyrosine kinases. Biochemistry 42: 10348-10353

Castanho VS, Nakamura RT, Pinto-Neto AM And De FARIA EC. 2012. Postmenopausal therapy reduces catalase activity and attenuates cardiovascular risk. Arq Bras Cardiol 99: 1008-1014.

Ciavattini A, Di Giuseppe J, Stortoni P, Montik N, GIANNUBILO SR, LITTA P, ISLAM MS, TRANQUILLI AL, REIS FM AND CIARMELA P. 2013. Uterine fibroids: pathogenesis and interactions with endometrium and endomyometrial junction. Obstet Gynecol Int 2013: 173184.
Doshi SB AND AgARWAL A. 2013. The role of oxidative stress in menopause. J Midlife Health 4: 140-146.

EVANS P AND BRUNSELL S. 2007. Uterine fibroid tumors: Diagnosis and treatment. Am Fam Physician 75: 1503-1508.

Ferrer-Sueta G, Manta B, Botti H, Radi R, Trujillo M AND DENICOLA A. 2011. Factors affecting protein thiol reactivity and specificity in peroxide reduction. Chem Res Toxicol 24: 434-450.

Flake GP, ANDERSEN J AND DixOn J. 2003. Etiology and pathogenesis of uterine leiomyomas: a review. Environ Health Perspect 111: 1037-1054.

Houston KD, Hunter DS, Hodges LC AND WALKer CL. 2001. Uterine leiomyomas: mechanisms of tumorigenesis. Toxicol Pathol 29: 100-104.

KovÁcs KA, OsZTER A, GÖcze PM, KÖRNYEI JL AND SZABÓ I. 2001. Comparative analysis of cyclin D1 and oestrogen receptor $(\alpha$ and $\beta$ ) levels in human leiomyoma and adjacent myometrium. Mol Hum Reprod 7: 1085-1091.

Li M, ZHAO L, LIU J, LIU AL, ZENG W.S., LUO SQ AND BAI XC. 2009. Hydrogen peroxide induces $G_{2}$ cell cycle arrest and inhibits cell proliferation in osteoblasts. Anat Rec 292: 1107-1113.

LOwry OH, Rosebrough NJ, FARR AL AND RANDALL RJ. 1951. Protein measurement with the Folin phenol reagent. J Biol Chem 193: 265-275.

LutosŁawska G, TKACZYK J, PANCZENKO-KRESOWSKA B, HÜBNER-WoźniaK E, SKIERSKA E AND GAJEWSKI A. 2003. Plasma TBARS, blood GSH concentrations, and erythrocyte antioxidant enzyme activities in regularly menstruating women with ovulatory and anovulatory menstrual cycles. Clin Chim Acta 331: 159-163.

Maruo T, Ohara N, Wang J and Matsuo H. 2004. Sex steroidal regulation of uterine leiomyoma growth and apoptosis. Hum Reprod Update 10: 207-220.

Massafra C, Buonocore G, Berni S, Gioia D, Giuliani A AND Vezzosi P. 1993. Antioxidant erythrocyte enzyme activities during oral contraception. Contraception 47 : 591-596.

Massafra C, Buonocore G, Gioia D And SARgentini I. 1996. Changes in the erythrocyte antioxidant enzyme system during transdermal estradiol therapy for secondary amenorrhea. Gynecol Endocrinol 10: 1-4.

Massafra C, Buonocore G, Gioia D, SARgentini I AND FARINA G. 1997. Effects of estradiol and medroxyprogesterone acetate treatment on erythrocyte antioxidant enzyme activities and malondialdehyde plasma levels in amenorrhoic women. J Clin Endocrinol Metabol 82: 173-175.

Massafra C, De Felice C, Giola D and Buonocore G. 1998. Variations in erythrocyte antioxidant glutathione peroxidase activity during the menstrual cycle. Clin Endocrinol 49: 63-67.

Massafra C, Gioia D, De Felice C, Picciolini E, De Leo V, BONIFAZI M AND BERNABEI A. 2000. Effects of estrogens and androgens on erythrocyte antioxidant superoxide dismutase, catalase and glutathione peroxidase activities during the menstrual cycle. J Endocrinol 167: 447-452. 
NEUWIRTH R AND MORITZ J. 2008. Leiomyoma of the Uterus. (ISSN: 1756-2228). DOI 10.3843/GLOWM.10007

NGô C, ChÉreau C, Nicco C, Weill B, Chapron C And BATTEUX F. 2009. Reactive oxygen species controls endometriosis progression. Am J Pathol 175: 225-234.

Pejić S, Todorović A, Stojiljković V, CVetKović DD, LuČIĆ N, RADOJIČIĆ RM, SAIČIĆ ZS AND PAJOVIĆ SB. 2008. Superoxide dismutase and lipid hydroperoxides in blood and endometrial tissue of patients with benign, hyperplastic and malignant endometrium. An Acad Bras Cienc 80: 515-522.

PejIĆ S, TOdorović A, StoJILJKović V, KASAPOVIĆ J AND PAJOVIĆ SB. 2009. Antioxidant enzymes and lipid peroxidation in endometrium of patients with polyps, myoma, hyperplasia and adenocarcinoma. Reprod Biol Endocrinol 23: 149.

REIN MS. 2000. Advances in uterine leiomyoma research: the progesterone hypothesis. Environ Health Perspect 108: 791-793.

SABuncU T, Vural H, HaRma M AND Harma M. 2001. Oxidative stress in polycystic ovary syndrome and its contribution to the risk of cardiovascular disease. Clin Biochem 43: 407-413.

Serviddio G, Loverro G, Vicino M, Prigigallo F, Grattagliano I, Altomare E and Vendemiale G. 2002. Modulation of endometrial redox balance during the menstrual cycle: relation with sex hormones. J Clin Endocrinol Metab 87: 2843-2848.

SHINDE A, GANU J AND NAIK P. 2012. Effect of free radicals \& antioxidants on oxidative stress: a review. J Dent Allied Sci 1: 63-66.

SIES H. 2014. Role of metabolic $\mathrm{H}_{2} \mathrm{O}_{2}$ generation: redox signaling and oxidative stress. J Biol Chem 289: 8735-8741.
Strobelt N, Ghidini A, Cavallone M, Pensabene I, Ceruti P AND VERGANI P. 1994. Natural history of uterine leiomyomas in pregnancy. J Ultrasound Med 13: 399-401.

SuGINO N AND KATO H. 1994. The role of ischemia-reperfusion injuries in generating reactive oxygen species during luteolysis. Adv Contra Deliv Syst 10: 95-106.

Sugino N, Kashida S, Takiguchi S, NaKamura Y AND KATO H. 2000. Induction of superoxide dismutase by decidualization in human endometrial stromal cells. Mol Hum Reprod 6: 178-184.

Tranquilli AL, Mazzanti L, Cugini AM, Cester N, GARZETTI GG AND RomAINI C. 1995. Transdermal estradiol and medroxyprogesterone acetate in hormone replacement therapy are both antioxidants. Gynecol Endocrinol 9: 137-141.

Vaishali S, Sanjeev S, NeElima S and Shaila S. 2005. Status of antioxidant enzymes and trace metals in postmenopausal women. J Obstet Gynecol India, 55: 64-66.

WALLACH EE AND VlaHOS NF. 2004. Uterine myomas: An overview of development, clinical features, and management. Obstet Gynecol 104: 393-406.

WANG Y, MATSUO H, KURACHI O AND Maruo T. 2002. Downregulation of proliferation and up-regulation of apoptosis by gonadotropin-releasing hormone agonist in cultured uterine leiomyoma cells. Eur J Endocrinol 146: 447-456.

WEINTRAUB JL AND YEMIN A. 2011. Endovascular treatment of uterine fibroids. US Radiology 1: 63-69.

Yu L, MoORE AB AND DiXON D. 2010. Receptor tyrosine kinases and their hormonal regulation in uterine leiomyoma. Semin Reprod Med 28: 250-259. 